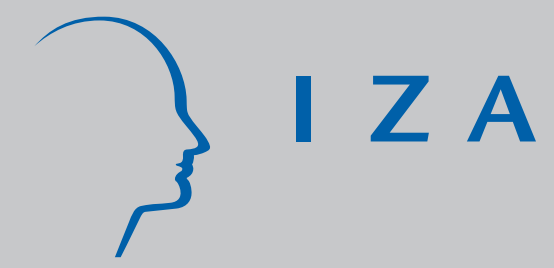

IZA DP No. 36

The Effects of European Economic and Monetary Union on Wage Behaviour

Charlotte Lauer

March 1999 


\title{
The Effects of European Economic and Monetary Union on Wage Behaviour
}

\author{
Charlotte Lauer
}

\author{
Discussion Paper No. 36 \\ March 1999
}

\author{
IZA \\ P.O. Box 7240 \\ D-53072 Bonn \\ Germany \\ Tel.: +49-228-3894-0 \\ Fax: +49-228-3894-210 \\ Email: iza@iza.org
}

This Discussion Paper is issued within the framework of IZA's research areas Mobility and Flexibility of Labor Markets and Internationalization of Labor Markets and European Integration. Any opinions expressed here are those of the author(s) and not those of the institute. Research disseminated by IZA may include views on policy, but the institute itself takes no institutional policy positions.

The Institute for the Study of Labor (IZA) in Bonn is a local and virtual international research center and a place of communication between science, politics and business. IZA is an independent, nonprofit limited liability company (Gesellschaft mit beschränkter Haftung) supported by the Deutsche Post AG. The center is associated with the University of Bonn and offers a stimulating research environment through its research networks, research support, and visitors and doctoral programs. IZA engages in (i) original and internationally competitive research in all fields of labor economics, (ii) development of policy concepts, and (iii) dissemination of research results and concepts to the interested public. The current research program deals with (1) mobility and flexibility of labor markets, (2) internationalization of labor markets and European integration, (3) the welfare state and labor markets, (4) labor markets in transition, (5) the future of work, and (6) general labor economics.

IZA Discussion Papers often represent preliminary work and are circulated to encourage discussion. Citation of such a paper should account for its provisional character. 
IZA Discussion Paper No. 36

March 1999

\section{ABSTRACT}

\section{The Effects of European Economic and Monetary Union on Wage Behaviour ${ }^{*}$}

This paper evaluates the possible consequences of the forthcoming European and Monetary Union on wage behaviour. It will be shown that EMU does not influence wage policy directly, but rather indirectly through its implications on other areas of economic policy, predominantly on monetary policy. Consequently, EMU will put increasing pressure on using wage policy as a flexible adjustment variable, since other adjustment mechanisms shall cease to exist. Six European countries were analysed empirically, which showed that in the past, southern European countries conducted a much more expansive wage policy than northern European countries. However, this competitive disadvantage of the southern countries was more than compensated by exchange rate developments. What will happen when EMU has come into effect? Either fewer devaluation possibilities within EMU will lead to a shift in competitive positions in favour of the northern countries, or a change in wage behaviour will be observed. The descriptive analysis shows that, on the eve of EMU, wage policy has become more moderate. This trend could be accelerated by the arrival of EMU. The econometric analysis provides an argument for this: the stability of exchange rates have been proven to have a dampening effect on wage increases in the past, particularly in southern European countries. Whether the extent of these effects will be sufficient to prevent a shift in relative competitive positions, however, remains to be seen.

JEL Classification: J20, E24, E52

Keywords: European Monetary Union, Euro, wage behaviour, wage policy

Charlotte Lauer

Department of Labour Economics, Human Resources and

Social Policy

Centre for European Economic Research (ZEW)

P.O. Box 103443

D-68034 Mannheim

Germany

Tel.: +49621 1235285

Fax: +496211235225

email: lauer@zew.de

\footnotetext{
This research was supported by Deutsche Post AG under the project „Labour Market Effects of European Monetary Union“. I would like to thank Viktor Steiner for his helpful suggestions and comments.
} 


\section{Non-technical summary}

The aim of this paper is to evaluate the possible consequences of the forthcoming European and Monetary Union on wage behaviour. The focus is on the outcome of wage negotiations rather than on the process of wage determination. It was shown that EMU does not influence wage policy directly, but rather indirectly through its implications on other areas of economic policy, predominantly on monetary policy. Indeed, as a consequence of EMU, economic policy will be increasingly conducted at the European level. The loss of national adjustment variables, such as the exchange rate or the interest rate, will result in an increased need for alternative flexible mechanisms to correct possible asymmetric shocks between EMU countries. Therefore, given that other adjustment mechanisms such as an extended system of fiscal transfers or enhanced labour mobility seem somewhat unrealistic in the specific case of the $\mathrm{EU}$, pressure on wage policy towards greater flexibility, particularly regarding productivity developments, is expected to increase under EMU.

For the purpose of the empirical analysis, six European countries which will be part of EMU in the first round were selected for detailed analysis with respect to their wage behaviour : Germany, the Netherlands, France, Italy, Spain and Portugal. The aim was to deduce from an analysis of past performance indications of a possible future wage behaviour when EMU has come into effect. A descriptive analysis was complemented with an econometric analysis. Firstly, the position of wage policy and its consequences over the last thirty years were analysed by observing unit labour costs for the six countries chosen, which measure the relationship between wages and productivity. It was shown that in the past, southern European countries conducted a much more expansive wage policy than northern European countries, since wages increased at a faster rate than productivity to a larger extent than in northern European countries. However, this disadvantage of the southern European countries in terms of international competitiveness turned out to be more than compensated by exchange rate developments : Due to a continuous devaluation of the southern European currencies over the period studied, the southern countries were able to maintain their international competitive position at an EU-similar level. Conversely, the competitive advantage of the northern European countries resulting from more moderate wage developments with respect to productivity has been equalised by the relative appreciation of their currencies.

This is why the empirical analysis also examined the question whether fewer devaluation possibilities within EMU should lead to a favourable shift in the competitive positions of the northern European countries, or whether the countries will adapt and change their wage behaviour. It could be shown that a trend shift has already occurred in wage behaviour, which, on the eve of EMU, has become more moderate. This trend could be accelerated by EMU coming into effect. The econometric analysis provides an argument for this: The stability of exchange rates has shown to have had a dampening effect on wage increases in the past, particularly in the southern European countries. This suggests that the transition to EMU, which implies de facto stable exchange rates within EMU member states, should lead to a more moderate policy, especially in those countries which traditionally conducted an expansive wage policy. EMU could bring about even stronger effects since the stability of exchange rates is far more credible in a monetary union and can be integrated in the expectations of economic agents in a more consequent way. Whether the extent of these effects will be sufficient to prevent a shift in relative competitive positions, however, remains to be seen. 


\section{Introduction}

Under the Maastricht Treaty, the member states of the European Community committed to complete a European Economic and Monetary Union (EEMU) at the latest by $1^{\text {st }}$ January 1999. From this date, a common currency is to be introduced in the European member states participating in the European and Monetary Union. This common currency will be issued and controlled by the European Central Bank (ECB). In other words, monetary and exchange rate policy will be centralised at the European level. The implementation of EMU will radically change the macro-political framework in which national economic policy operates by imposing decisive restrictions of national autonomy with respect to economic policy, which will be increasingly conducted jointly at the European level. Of course, wage policy will not be directly affected by the introduction of a common currency in Europe. It will be decided upon at the national level just as before. However, because the advent of EMU changes the economic policy-making environment, it will also have an impact on wage behaviour.

The primary aim of this paper is to discuss the extent to which wage behaviour will be affected by the forthcoming European and Monetary Union. The focus is on the outcome of wage negotiations rather than on the process of wage determination (see Boockman 1999 for a treatment of the latter issue). It will be seen that, from the point of view of wage policy, the main consequences of EMU lie in the loss of national adjustment variables, such as the exchange rate or the interest rate and in the resulting need for alternative flexible mechanisms to correct possible asymmetric shocks between EMU countries. Wage policy as such potential adjustment instrument is due to play an essential role. Another aim of this paper is to evaluate whether wage policy in Europe is likely to prove to be sufficiently adaptable to the new EMU environment, i.e. whether national policy-makers are likely to take the increased significance of wage behaviour into account by demonstrating some kind of increased flexibility.

For the purpose of the empirical analysis, six European countries were selected for detailed analysis with respect to their wage behaviour. The descriptive analysis is complemented with an econometric analysis. The aim is to deduce from an analysis of past performance indications of a possible future wage behaviour when EMU has come into effect. Firstly, the position of wage policy and its consequences over the last thirty years is analysed by observing unit labour costs for the six countries chosen. Exchange rate developments in the past are given special attention, since the introduction of EMU removes exchange rate variations within EMU countries. The econometric analysis complements the descriptive analysis and evaluates the flexibility of wage behaviour over the period considering variables such as productivity, unemployment or inflation and, of course, the exchange rate regime. In particular, the question, whether periods of relative exchange rate stability have had an effect on wage behaviour will be analysed, in which case one could conclude that the advent of EMU should bring about a similar effect.

This paper is structured as follows. Following the introduction, section 2 explains the extent to which European Monetary Union should have an impact on wage behaviour. A brief overview of possible wage scenarios and their consequences within the framework of EMU will be given. In section 3, a descriptive analysis of past wage behaviour in six representative EMU countries will be conducted, preceding the econometric analysis in section 4. Finally, the main conclusions will be drawn with respect to the expected effects of EMU on wage behaviour, as well as to the possible consequences.

\section{Consequences of EMU on the framework of wage determination}

European Monetary Union does not directly affect the framework of wage formation, but rather indirectly, through the fact that other areas of economic policy-making will lose autonomy in a decisive way. 
- Monetary and exchange rate policies are mostly affected, which are transferred from the national to the European level and therefore become an exogenous factor. This has two relevant implications for wage policy:

First, as stipulated in the Treaty, price stability becomes the primary objective of monetary policy. Although wage policy is due to be further conducted at the national level even after EMU has come into effect, its autonomy may be restricted by the policy of the European Central Bank. Let us suppose for instance that one country conducts a very expansive wage policy. This could lead to inflationary tendencies, which the ECB might wish to counteract by raising the interest rate or applying a stringent monetary policy.

Second, the implementation of the third stage of EMU implies that intra-european exchange rates will be kept irrevocably fixed. In other words, due to EMU, member-states lose the opportunity to make use of the exchange rate as an instrument to correct macroeconomic disequilibria. In particular, they cannot devalue their own currency so as to restore international price competitiveness. At this stage, it is worth noting that the use of devaluation as an adjustment mechanism is questionable (Müller 1999a, 1999b). This is because devaluating makes imports more expensive, which in turn induces price increases (Dohse 1998, Matthes 1992). Consequently, real wages suffer losses, which could lead to compensatory wage claims and eventually trigger off an upward wage-price-spiral. Over time, this would wipe out the positive initial effect of devaluation on competitiveness. This phenomenon seems to be confirmed by real empirical observation (De Grauwe 1994, EC Commission 1991). However, whether they are effective in the middle run or not, devaluations are used as an adjustment mechanism at least because of their ability to influence the time path of the adjustment process. Without nominal devaluation, price and wage rigidity firstly impede the required adjustment of the real exchange rate and the consequential negative shock leads to an initial loss in production. A devaluation enables a reduction in the initial production loss. On the other hand, as shown in the simulations of the EC Commission-study (EC Commission 1991), the restoration of equilibrium needs more time than without a nominal devaluation - prices and wages adapt after a while - and is accompanied by more inflation. Devaluating represents a trade-off between faster adjustment in the short-run and delayed adjustment in the middle-run (EC Commission 1991), but at least in the short run it seems to be a mechanism to avoid having to adjust through wages and prices or some other more painful adjustment mechanism.

- The autonomy of fiscal policy is also restricted by EMU, though the restriction is far from the same extent as that of monetary policy. Even after EMU has come into force, fiscal policy will remain under the control of national governments. However, EMU does impose fiscal constraints. Certainly, not EMU has created the necessity of having sound finances, but with the required fiscal convergence criteria, EMU does impose clear upper limits for fiscal deficits and indebtedness, as well as a precise point in time, at which EMUcandidates have to fall below those upper limits. Given the initial fiscal situation of many countries, this puts fiscal policy under great pressure. As a result, national governments lose some room for manoeuvre, at least in the consolidation phase, to use fiscal policy as an instrument to boost economic activity. Again, one can discuss whether expanding fiscal transfers to the economy is an appropriate way to boost the economy in a sustainable way, but at least in the short run, it is an unquestionable way of relieving pressure on the economy without having to rely on more painful adjustment mechanisms. Due to the evoked fiscal constraints emerging with EMU, it may prove more difficult to use expansive 
fiscal policy in order, for instance, to compensate for the consequences of excessive wage increases on the labour market.

Since European Monetary Union brings about some further restrictions for national autonomy in economic policy-making, other adjustment mechanisms have to be relied upon to compensate for possible asymmetric shocks or disequilibria between EMU-countries. Referring to the theory of optimum currency area (Mundell 1961, Siebert 1997, De Grauwe 1994), there remain principally three adjustment mechanisms in a monetary union :

- A system of fiscal transfers : Such a system, usual in most federal states, would help restore the balance by providing unilateral transfers to regions affected by an asymmetric shock. This option, however, does not seem very realistic in the context of the EU, since the EU is a bundle of independent sovereign states, rather than a federation, who are expected to show reluctance to this kind of financial solidarity (Eichengreen 1990, De Grauwe 1994). As a matter of fact, the current size of the EU-budget (some 1.3\% of EUGDP) is too insignificant to have an equalising effect (Büttner 1999), and in view of the forthcoming enlargement of the EU by eastern European countries, which will weigh heavily on the EU budget, the extension of fiscal transfers in a system similar to fiscal equalisation between government and local authorities within a federal state does not seem likely to happen.

- Labour mobility : Labour mobility could serve as an adjustment mechanism in the sense that the unemployed of one region could move to a region where there is a labour demand surplus. Legal provisions for labour mobility have already been created in the EU. In practice, however, labour mobility is very low in the EU (Puhani 1999), e.g. in comparison to labour mobility in the USA. Furthermore, it is unlikely to increase in a decisive way under EMU, because the low mobility in the EU is essentially due to language and cultural barriers, which will also continue to prevail in the middle-run. Moreover, this option of using labour mobility as an adjustment mechanism would contradict one of the objectives of the EU, which is to promote a balanced social and economic development in the whole EU-area.

- Wage flexibility : Another way to adjust in the case of an asymmetric shock or disequilibrium could be that wages in the affected region fall or do not rise as much as in the better performing regions. This adjustment would help the region to improve its competitive position. The question is now whether wage policy will prove flexible enough to play the role of an adjustment instrument in the EMU zone.

To summarise, transition to EMU implies a decisive restriction of national autonomy in economic policy-making and the loss of adjustment mechanisms at the national level. Therefore, assuming that country-specific shocks might happen and given that other adjustment mechanisms such as an extended system of fiscal transfers or enhanced labour mobility seem somewhat unrealistic in the specific case of the EU, pressure on wages towards greater flexibility is expected to increase under EMU. However, how the architects of wage policy react to this probable enhanced pressure is another question.

In principle, they can adopt three types of wage policy. Let us now see what are the arguments in favour of each of these scenarios in the case of EMU :

- Productivity-oriented wage policy : In this scenario, wage increases strictly follow the increase in productivity. Such a policy aims at leaving unit labour costs unchanged.

Proponents of this scenario highlight the fact that within a monetary union aberrant wage developments, i.e. wage increases that do not take productivity developments into account, would be immediately sanctioned in terms of unemployment (Lesch 1995, Sievert 1993). This is because it is no longer possible within a monetary union to make use of monetary and exchange rate policy - or to a lesser extent of fiscal policy - to compensate for exaggerated 
wage increases. In other words, EMU will make it impossible for wage policy to offload its responsibility onto exchange rate or monetary policy. Therefore, increased international competition is due to discipline wage policy and the transition to EMU should bring about a change in the wage behaviour towards greater flexibility with regard to productivity developments. This holds especially in countries which would traditionally devaluate their currency in order to compensate for inflationary pressures coming from exaggerated wage increases (Matthes 1992, Dohse 1998).

- Expansive wage policy : In this scenario, wages increase at a faster rate than productivity. As a result, unit labour costs rise.

One reason for such a scenario could lie in the new transparency of wage differences due to EMU. Indeed, under EMU, all wages will be expressed in the same currency unit and therefore, the remains of exchange rate illusion will disappear (Lesch 1995). As a result, the poorer countries could be tempted to increase wages at a faster rate than economic development would allow (Fröhlich 1997), so as to achieve upward wage harmonisation. The rationale for such a scenario is not of an economic nature, but rather of a social or ethical one, according to the principle "same wage for same job" (Dohse 1998). From an economic point of view, such a policy would imply losses in terms of employment. An expansive wage policy in the poorer countries would satisfy the richer countries, since such a policy diminishes the competitive pressure coming from those low wage countries.

- Restrictive wage policy : In this scenario, wage increases are kept below the rate of increase in productivity. As a result, unit labour costs decrease.

Such a wage policy would aim at lowering unit labour costs in order to improve the competitive position of a specific country. If some European countries adopt this policy, the average wage level in Europe would get lower. The risk of such a policy is that partner countries may retaliate and adopt the same restrictive policy as well. This would trigger off a wage dumping process, which would result in an inefficient equilibrium with lower wages where no country improves its competitive position (Bush 1996).

In order to determine which of these scenarios is the most likely to happen within EMU, an empirical study of European wage behaviour has been conducted. Since EMU has not yet come into effect, it is not possible to empirically evaluate its consequences and one has to content oneself with examining the past in order to make predictions about the future. 


\section{EMU and wage behaviour : a descriptive analysis}

The following descriptive analysis of European wage behaviour relies mainly on the close examination of developments in unit labour costs. Unit labour costs can be interpreted as an indicator of the position of wage policy, since they measure the relationship between wages and productivity. Indeed, when unit labour costs increase (decrease), it means that wages increase faster (more slowly) than productivity and that wage policy is therefore expansive (restrictive). At this stage, the concept of unit labour costs has to be defined more accurately. One can differentiate between nominal and real unit labour costs. Using the definitions of Hardes (Hardes 1994) and Hübner (Hübner 1996) as well as of Eurostat, from which data has been taken, unit labour costs can be defined as follows ${ }^{1}$ :

Nominal unit labour costs $=\frac{\text { Nominal income from employment per person employed }}{\text { Real GDP per person in work }}$

Real unit labour costs $=\frac{\text { Real income from employment per person employed }}{\text { Real GDP per person in work }}$

Both nominal and real unit labour costs are an indicator of wage policy, but they highlight different aspects of wage policy :

- An increase in nominal unit labour costs means ceteris paribus that production becomes more expensive and that the competitive position deteriorates. Therefore, the development of nominal unit labour costs provides information about the competitive implications ${ }^{2}$ of wage policy. The mere analysis of nominal unit labour costs would not be enough, because it masks the influence of price developments.

- Real unit labour costs give information about the distribution of labour income in relation to capital income. When real unit labour costs increase (decrease), it means a shift in the income distribution relationship in favour of workers (capital owners) (Hardes 1994, Hübner 1996). Therefore, the development of real unit labour costs provides information about the distributive implications of wage policy.

For the purpose of the descriptive analysis as well as of the econometric analysis, the position of six European countries will be specifically analysed for the period between 1960 and 1996 . The countries analysed were chosen to provide a representative picture of the countries which will be part of EMU in the first round. Germany (G) and the Netherlands (NL) were chosen as typical representatives of northern European countries, characterised by a high wage level and a hard currency. At the other end, Spain (E) and Portugal (P) were chosen as typical representatives of southern European countries, typically characterised by a low wage level and a weaker currency. In addition, France $(F)$, which can be seen as belonging to the group of Northern European countries, was also chosen as well as Italy (I), which belongs to the group of southern European countries. The position of the latter countries will turn out to be in many respects rather intermediary. The groups defined above are used for the purpose of presenting the analysis and should not be considered as an analysis hypothesis. However, it

\footnotetext{
${ }^{1}$ The reason why the numerator refers to "person employed" and not to "person in work" like the denominator is that data relating to the income of independent workers is not available. Such a definition implies that the latter is supposed to be similar to the income of employees.

${ }^{2}$ In terms of price-competitiveness (qualitative aspects remaining unconsidered).
} 
may be interesting to examine whether the behaviour of a typical "northern EU country" can be observed as opposed to a typical "southern EU country".

As far as nominal unit labour costs ${ }^{3}$ are concerned, there is a clear distinction between Northern and Southern countries, as showed in the following two figures :

Figure 1a: Nominal unit labour costs 1960 - 1996

Germany, France, Netherlands

In national currency, $1960=100$

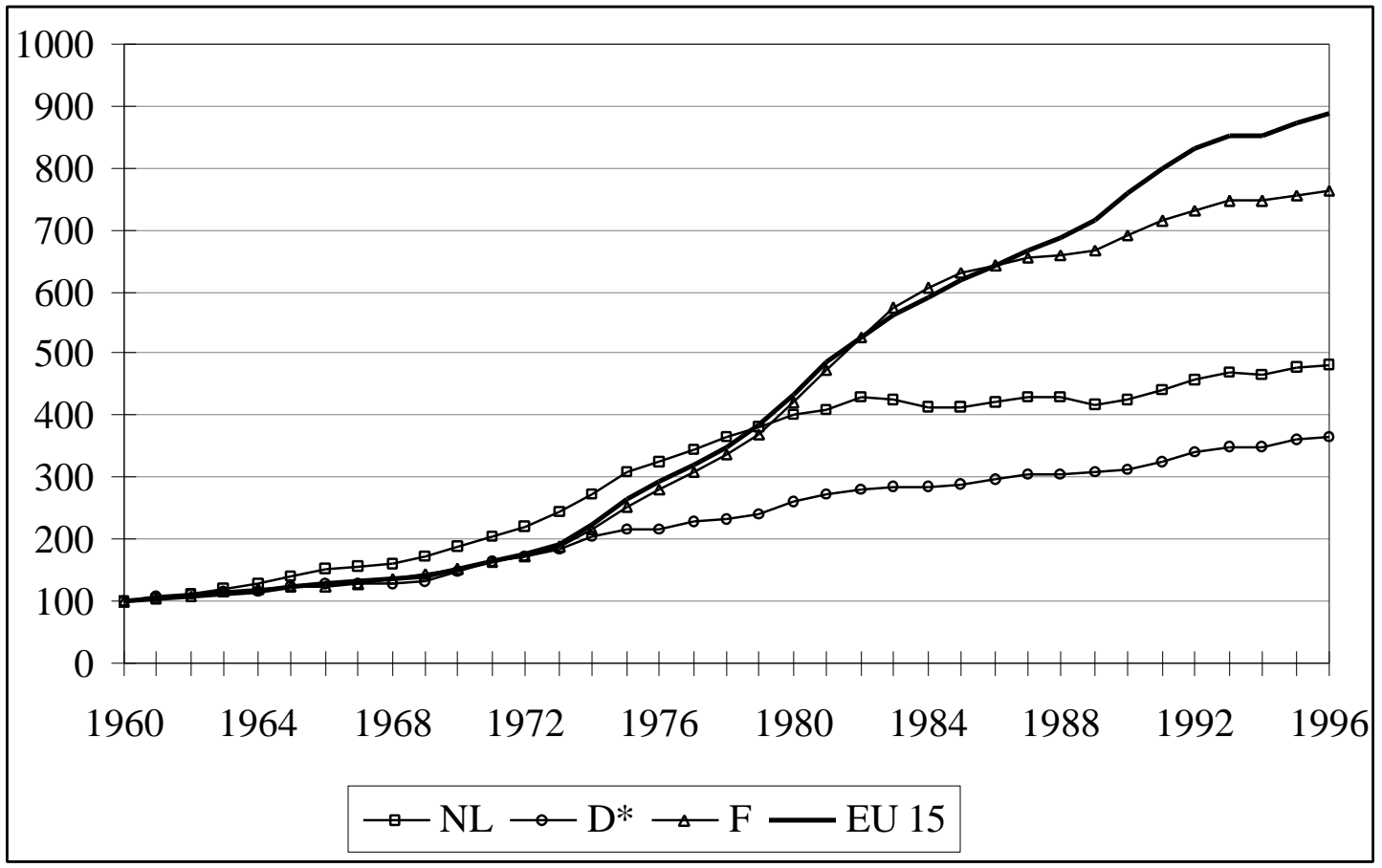

* Until 1994 : former West-Germany

Source : Eurostat

Figure 1b: Nominal unit labour costs 1960 - 1996 Italy, Spain, Portugal

\footnotetext{
${ }^{3}$ See in Appendix A1 the graph showing the respective positions in terms of wage and productivity levels.
} 
In national currency, $1960=100$

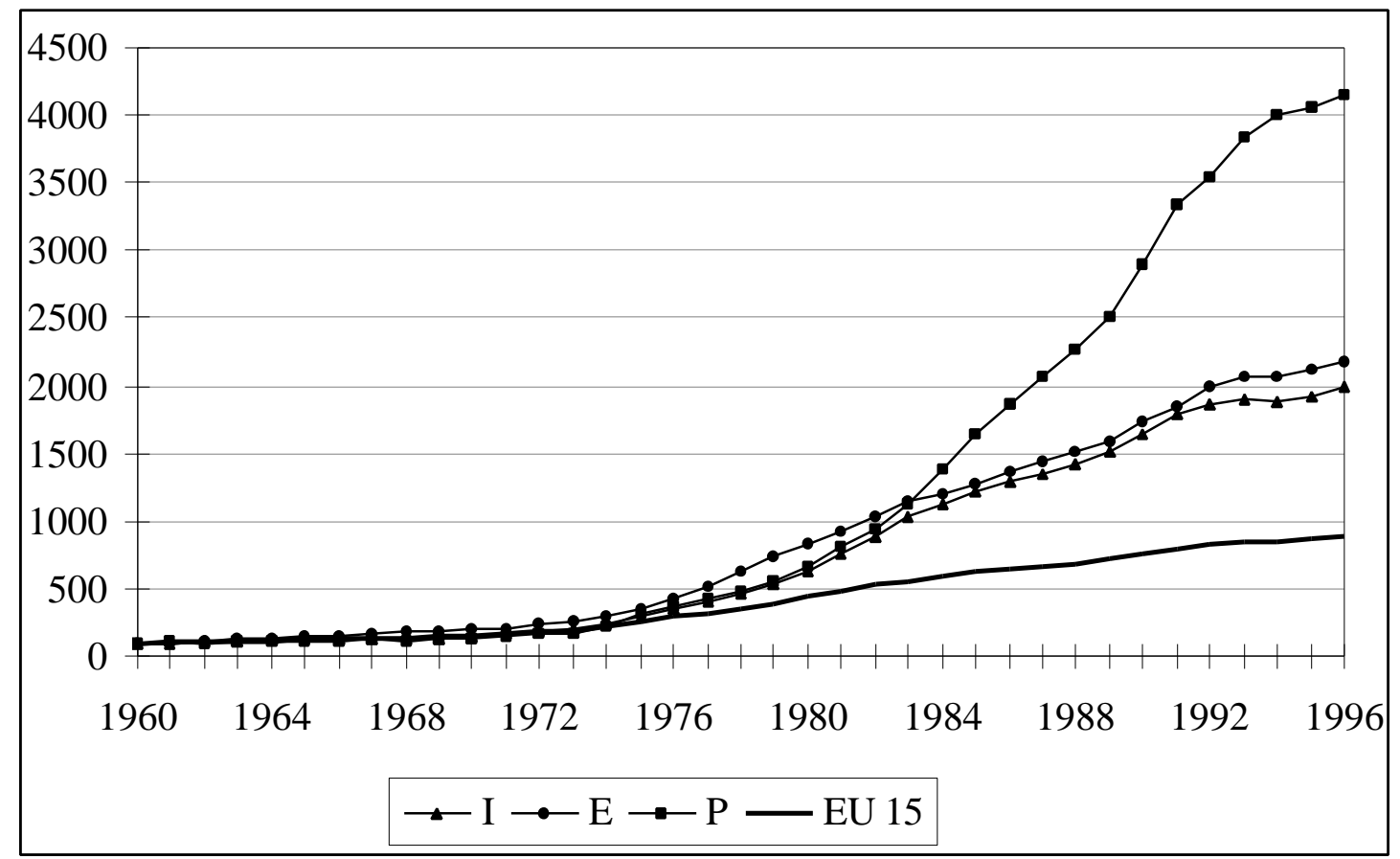

Source : Eurostat

As shown in the graphs above, nominal wages have increased in Europe (EU15) on average at a faster rate than productivity since 1960, since nominal unit labour costs have been increased nine-fold. Moreover, the northern countries experienced a slower wage expansion than the European average, and above all slower than the southern countries ${ }^{4}$. Judging from these graphs alone, one could conclude that:

- Southern countries have conducted a much more expansive wage policy than northern countries.

- Southern countries should experience a disadvantage in international competition compared to northern countries.

This would be too rapid a conclusion, since:

- Nominal unit labour cost developments hide huge inflation differentials (see Appendix A2). Therefore it is worth looking at the developments in real unit labour costs.

- Exchange rate developments also contribute to determining international price-competitiveness.

The following graphs shows the developments in real unit labour costs.

Figure 2a: Real unit labour costs 1960 - 1996

Germany, France, Netherlands

Consumer price deflator, $1960=100$

\footnotetext{
${ }^{4}$ Also within the groups, big differences can be observed : for instance, the final level of nominal unit labour costs in France is more than twice as high as that in Germany. Identically, the expansion of nominal wages in relation to productivity was much stronger in Portugal than in Spain and Italy.
} 


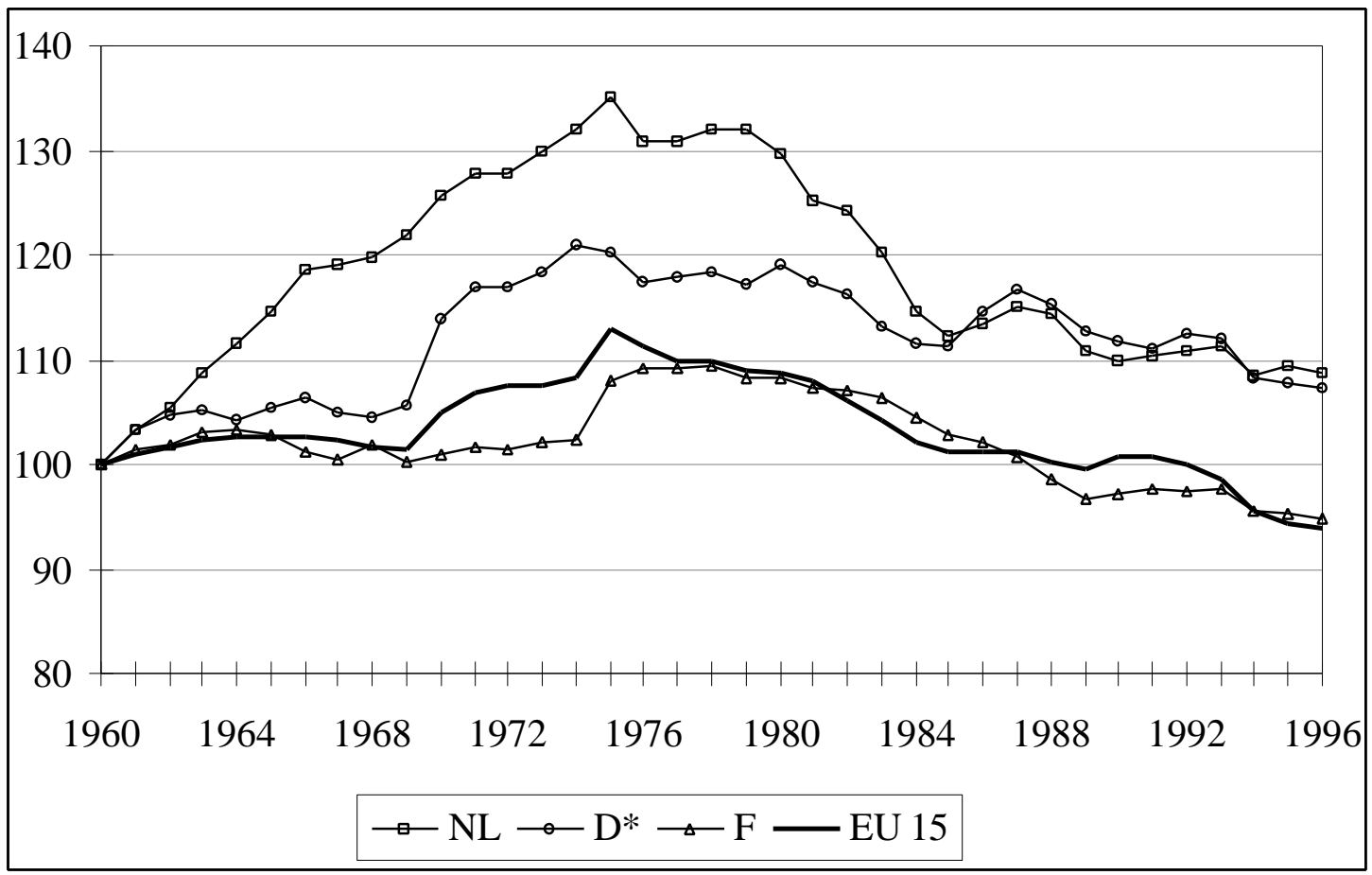

* Until 1994: former West-Germany

Source : Eurostat

Figure 2b: Real unit labour costs 1960 - 1996

Italy, Spain, Portugal

Consumer price deflator, $1960=100$

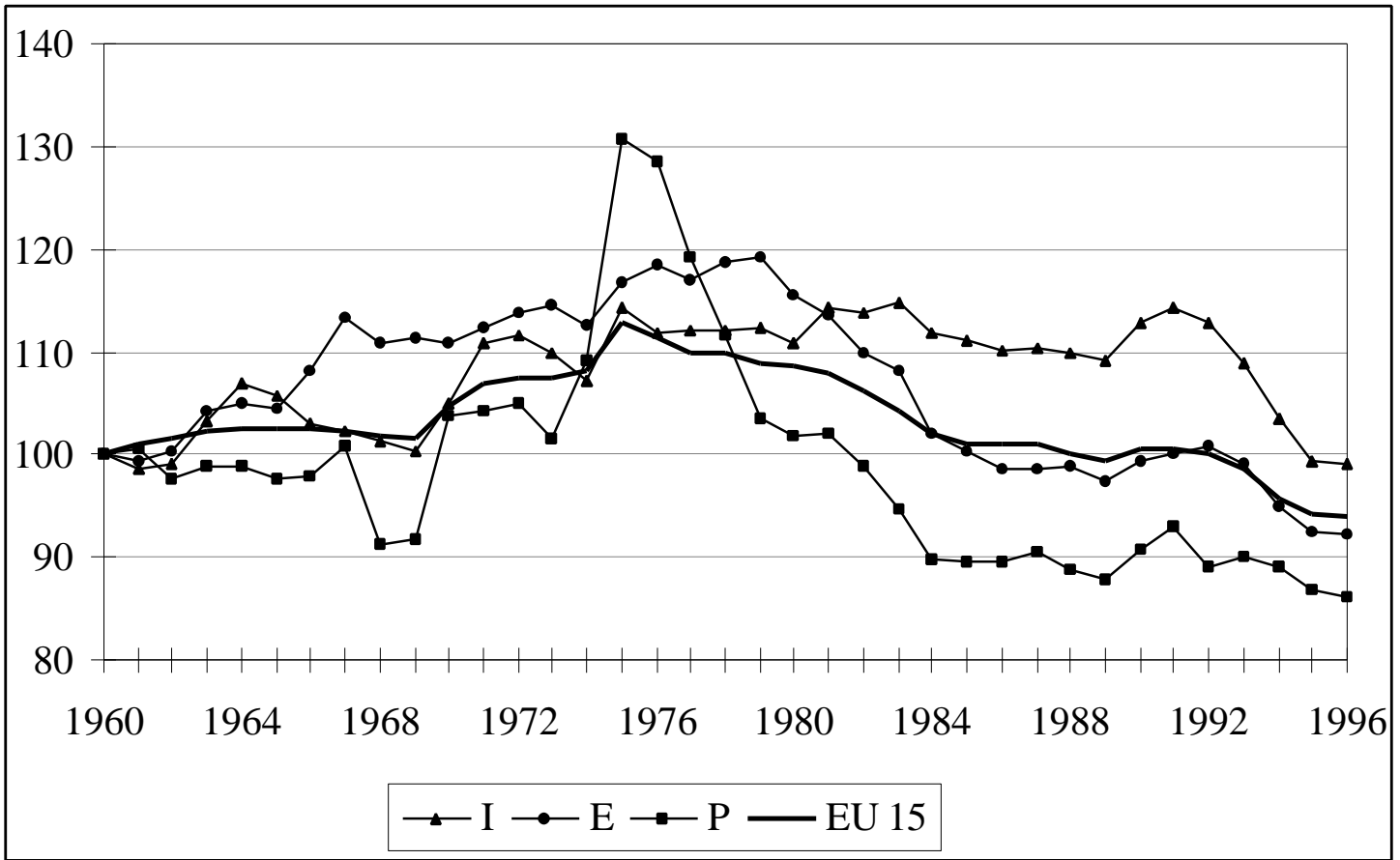

Source : Eurostat

As far as real unit labour costs are concerned, there is no longer such a clear distinction between the northern and the southern EU sample countries. This is because inflation was much higher in southern Europe than in the North over the period studied. In addition, the graphs show a trend towards a reduction in real unit labour costs since the middle of the seventies. This trend is particularly pronounced in the Netherlands, but also in Spain and Portugal, though this was partly a reaction to an extraordinary increase in the preceding period. This indicates a tendency to move towards a more restrictive 
wage policy, since inflation is not systematically equalised through nominal wage increases. This statement holds all the more since the inflation gap was reduced at the end of the period. It also means that capital owners improved there position relative to workers in the second part of the period analysed. However, the price level affects the international competitive position and even if wage policy does not fully match inflation, high-inflation southern countries should face a competitive disadvantage as long as nominal wages increase faster than productivity, all other things - in particular the exchange rate being equal.

This may not be the case if exchange rate developments compensate for the initial disadvantage. The following graphs shows the development of the nominal effective exchange rate. This exchange rate shows the development of the nominal exchange rate position in relation to the main trading partners, and is defined as the external value of the national currency in relation to the currencies of the main trading partners, where the bilateral exchange rates are weighted with the respective export shares ${ }^{5}$.

\section{Figure 3a: Effective nominal exchange rate* 1960-1996 Germany, France, Netherlands}

$1960=100$

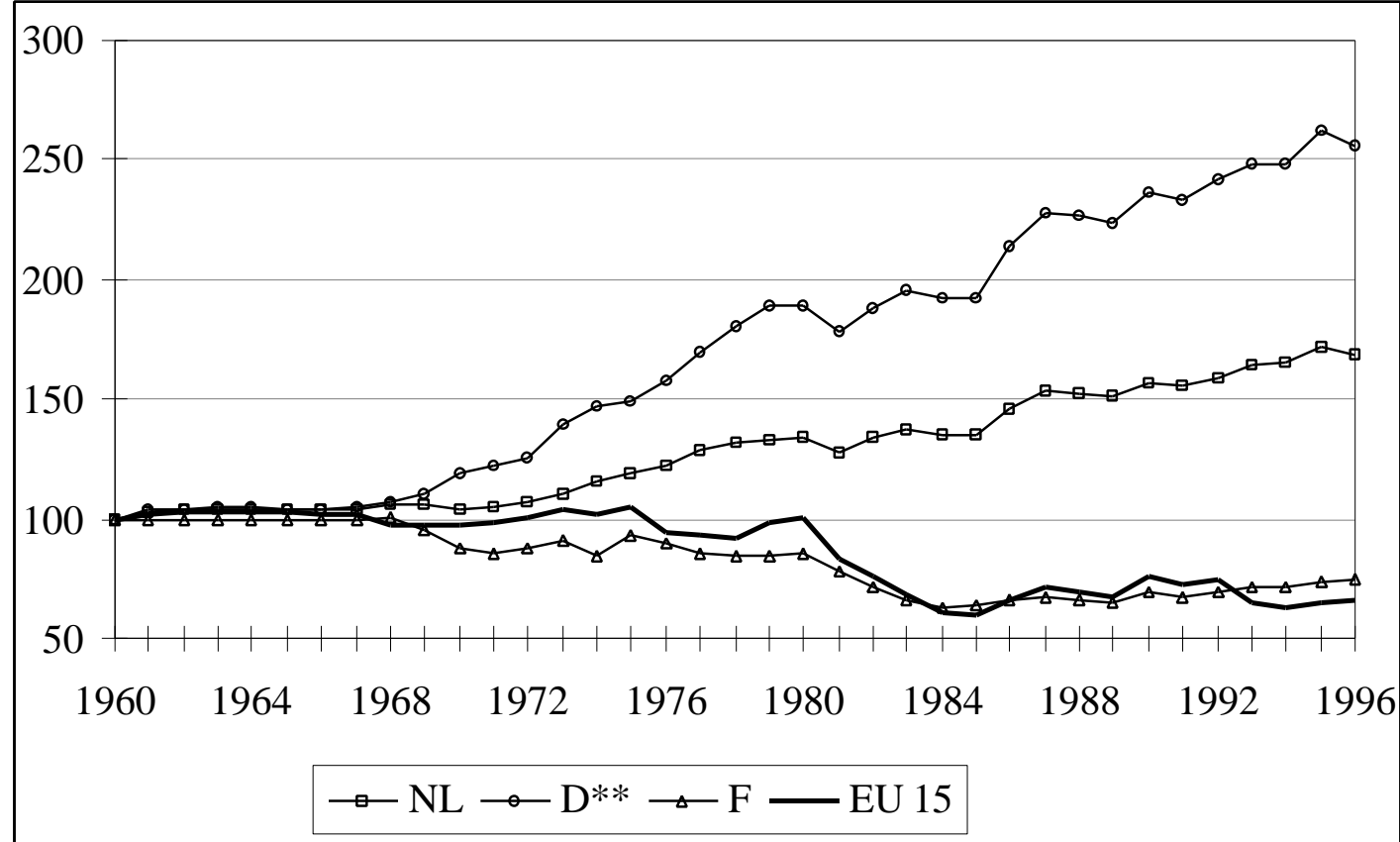

* Development of the external value of the national currency in relation to 19 industrialised countries and for EU 15 of the ECU in relation to 6 industrialised non-EU-countries, export weighting.

** Until 1994: former West Germany

Source: Eurostat, own calculations

\footnotetext{
${ }^{5}$ When the nominal effective exchange rate as defined here increases, it means that the currency is revalued.
} 
Figure 3b: Effective nominal exchange rate* 1960-1996

Italy, Spain, Portugal

$1960=100$

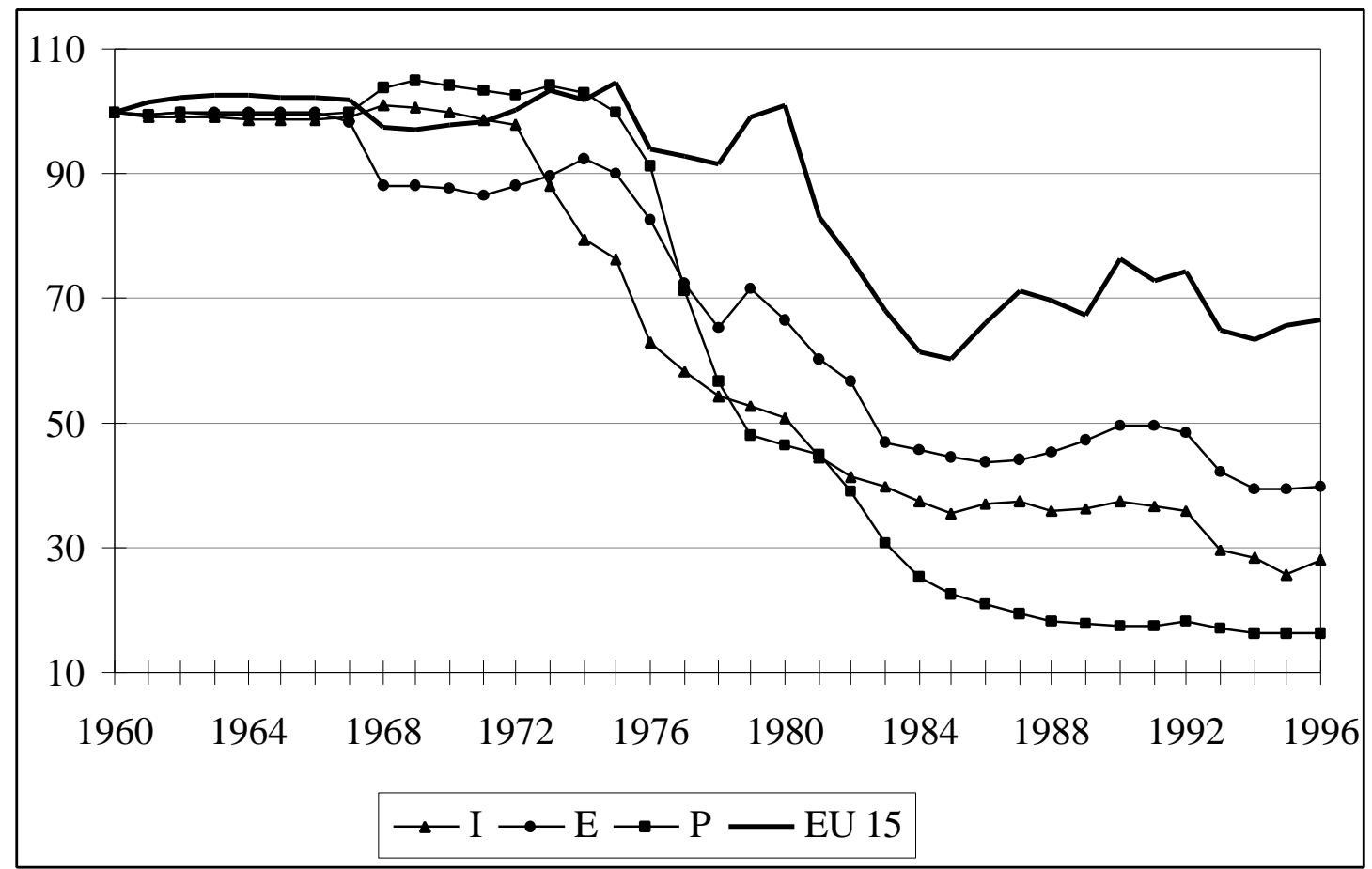

* development of the external value of the national currency in relation to 19 industrialised countries and for EU 15 of the ECU in relation to 6 industrialised non-EU-countries, export weighting.

Source: Eurostat, own calculations

These two graphs show very clearly that northern countries (Germany and the Netherlands) revalued their currency over the period, whereas southern countries devalued. With a slight devaluation, France's position is comparable to that of Europe as the whole. This means that northern countries are disadvantaged by the exchange rate developments in international competition relative to southern countries. Exchange rate developments and unit labour costs developments based on national currencies have turned out to have opposite effects on the competitive position of the selected countries.

In the following two graphs, nominal unit labour costs based on national currencies have been multiplied by the nominal effective exchange rate. The resulting effective nominal unit labour costs - no longer on the basis of national currency - sum up the wage and the exchange rate effects and gives an indication of the true competitive position. A comparison with the nominal unit labour costs on the basis of national currency before, makes it possible to imagine the changes in the relative competitive positions once exchange rate variations are limited by the introduction of EMU. 
Figure 4a : Effective nominal unit labour costs* 1960 - 1996 Germany, France, Netherlands

In foreign currency, $1960=100$

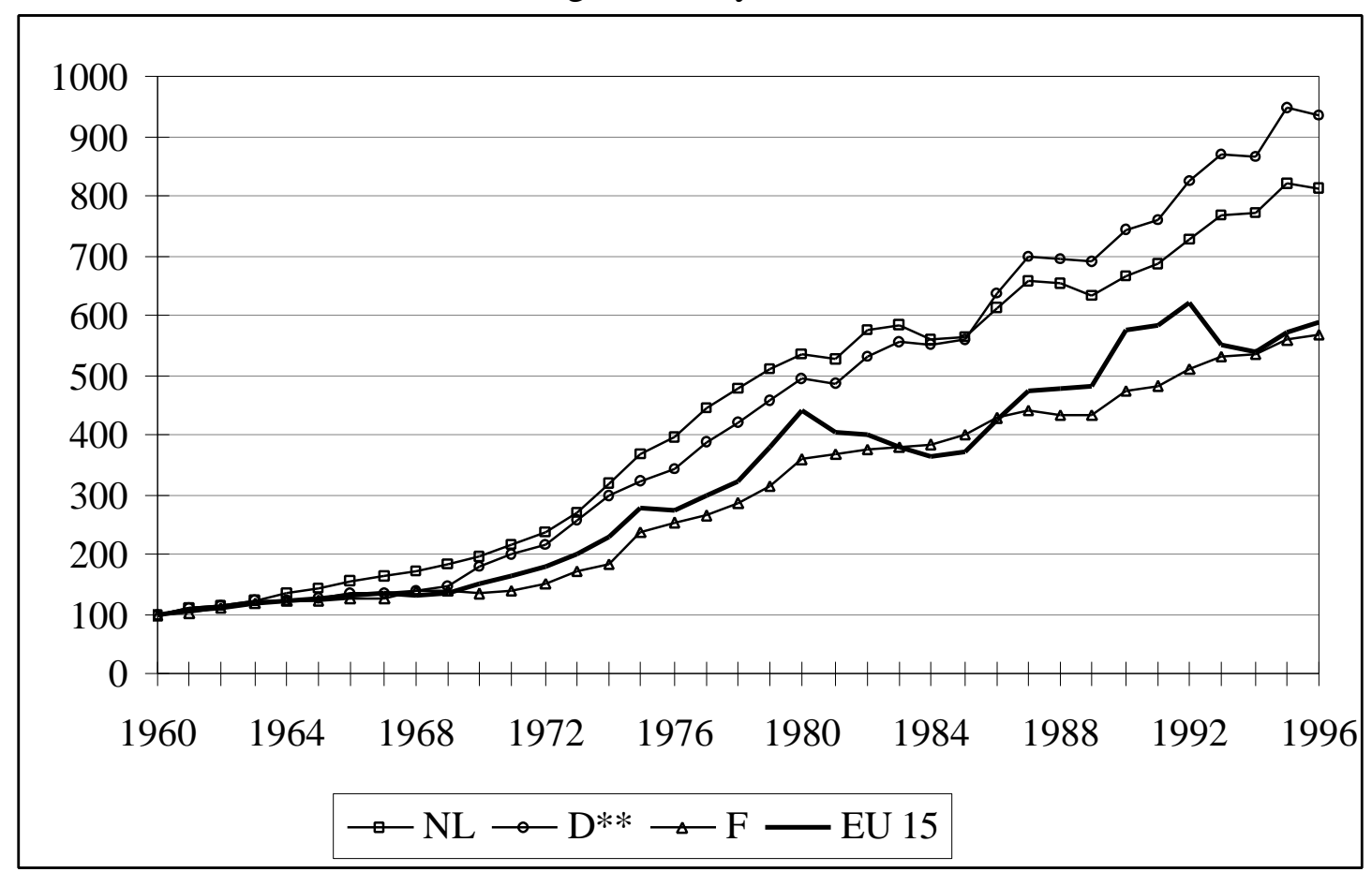

* Nominal unit labour costs in national currency, multiplied by the nominal effective exchange rate ** Until 1994: former West Germany

Source: Eurostat, own calculations

Figure 4b: Effective nominal unit labour costs* 1960 - 1996

Italy, Spain, Portugal

In foreign currency, $1960=100$

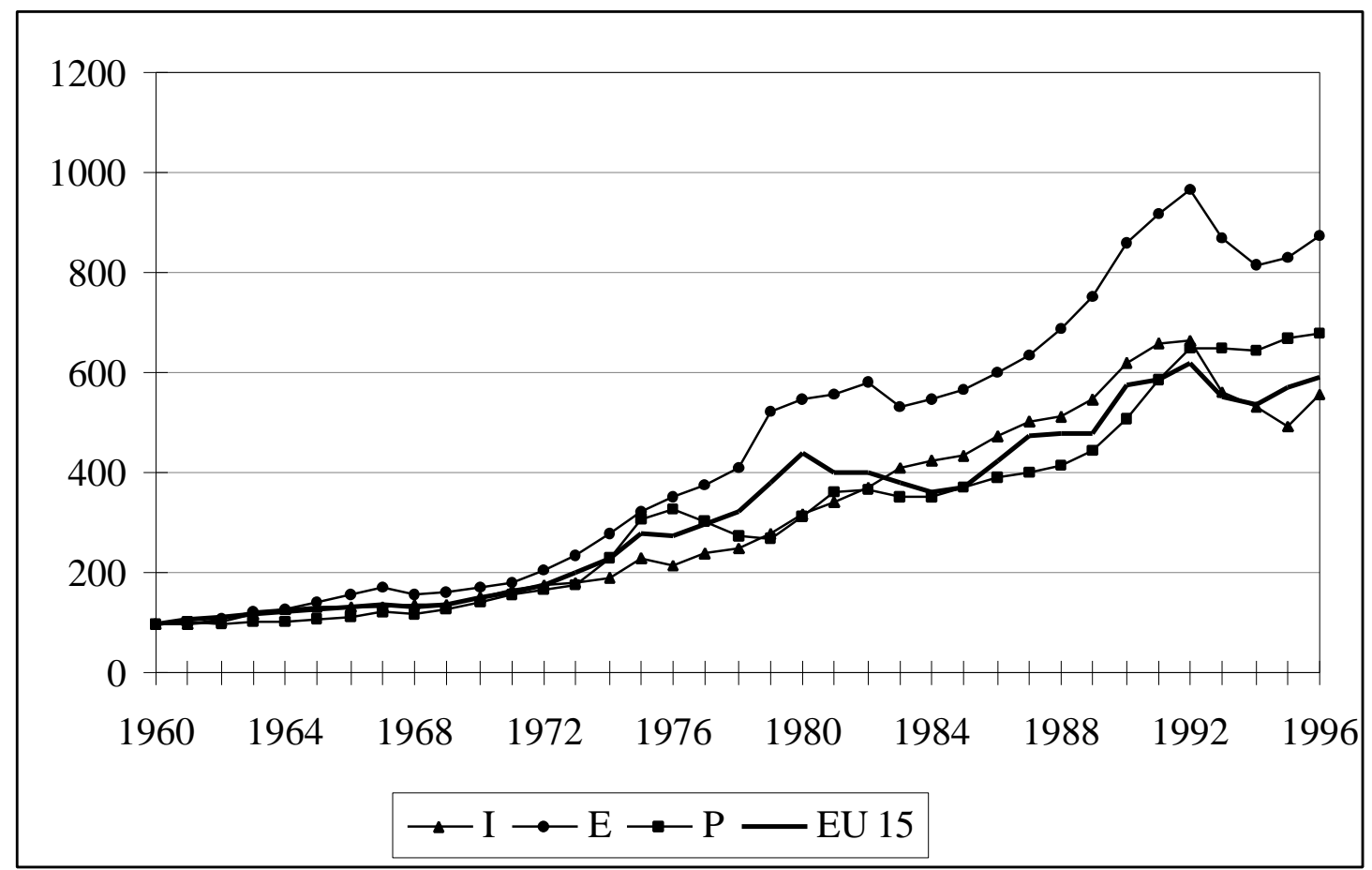

* Nominal unit labour costs in national currency, multiplied by the nominal effective exchange rate Source: Eurostat, own calculations 
The comparison of figures $4 \mathrm{a}$ and $4 \mathrm{~b}$ with figures $1 \mathrm{a}$ and $1 \mathrm{~b}$ shows that in Europe on the whole, exchange rate developments have reduced the competitive disadvantage coming from the expansive wage policy. As a matter of fact, once converted, nominal unit labour costs rose by about $600 \%$ over the period, whereas they increased by about $900 \%$ on the basis of national currency.

In both hard currency countries, Germany and the Netherlands, exchange rate developments have more than compensated the comparatively moderate wage policy. As a result, the competitive position of those countries has developed less favourably than that of the EU as the whole. Conversely, exchange rate developments have improved the situation of the southern countries, which should have been disadvantaged through international competition in view of their very expansive wage policy. For instance, due to devaluations, Italy and Portugal achieved a competitive position which is on the whole similar to that of the entire EU. Only in Spain, nominal unit labour costs remain above the EU-level, at levels comparable to Germany after conversion, which is nevertheless better than what would have happened in the absence of devaluation.

All in all, exchange rate policy has had an equalising effect on wage developments, since the competitive advantage of one group of countries and disadvantage of the other group have both been, at least partly, compensated for. After EMU comes into effect, the exchange rate as defined here will still be able to fluctuate, but to a far lesser extent, since the intra-European bilateral exchange rates - which concern the bulk of total trade of the European countries will be kept fixed. It implies that the possibility to rely on exchange rate policy to counteract unfavourable wage developments will be limited. The consequences of this depend on whether wage policy will adapt to the new conditions of EMU. If there is no change in wage policy, a significant shift in competitive positions within Europe will occur: the southern countries will lose international price-competitiveness - because they cannot devalue as much - and the northern countries will gain competitiveness - because they are not "forced" to suffer revaluations any longer. Conversely, wage negotiators could anticipate this and modify their behaviour accordingly by showing more moderation in wage claims. The following econometric analysis aims at complementing the analysis of wage behaviour in the six countries which have been chosen, hoping to provide additional suggestions about possible wage behaviour in the forthcoming EMU.

\section{EMU and wage behaviour : an econometric analysis}

The econometric analysis makes it possible to quantify the influence of several variables on wage increases in the six previously examined countries. In particular, a closer focus will be given to the role of the exchange rate.

\subsection{Objective}

The analysis of the consequences of EMU on the framework of wage determination as well as the descriptive analysis showed that transition to EMU requires greater wage flexibility. The aim of the following econometric analysis is to answer two questions :

- To what extent is there wage flexibility in Europe?

The degree of existing wage flexibility will be examined, especially as regards price, productivity, and unemployment developments. The greater wage flexibility, the less need for an adjustment within the framework of monetary union. Of particular interest is the question, whether a change in wage behaviour already occurred on the eve of Economic and Monetary Union. 
- Does the exchange rate regime influence wage behaviour?

It has been shown that the removal of the exchange rate instrument should lead to a change in wage behaviour towards greater flexibility, unless an erosion of competitiveness is to be deplored in the least flexible countries. The hypothesis whether agents follow this reasoning will be tested econometrically by examining the role of the exchange rate regime in the past in order to assess the possible consequences on wage behaviour in a regime of fixed exchange rates such as EMU.

\subsection{Specification of the wage equation}

The econometric model consists of a traditional wage equation derived from the Philips curve theory (Horn 1997, Tyrväinen 1995, Layard, Nickell and Jackman 1991). The econometric analysis focuses on examining the reaction of wage increases to all variables which have been found relevant for wage formation. All explanatory variables will be included separately in the wage equation. The wage equation which will be estimated takes an error-correction form, whereby the aim is to distinguish between short-run dynamics and long-run equilibrium.

The following wage equation will be estimated separately for each of the six countries.

$$
\Delta w_{t}=a_{0}+a_{1} \Delta p_{t}+a_{2} \Delta \gamma_{t}+a_{3} \Delta U_{t}+a_{4} \Delta w_{t-1}+\alpha\left(w_{t-1}-a_{00}-a_{10} p_{t-1}-a_{20} \gamma_{t-1}-a_{30} U_{t-1}-D_{f x_{t-1}}\right)+\varepsilon_{t}
$$

with $w_{t} \quad$ nominal wage at time $\mathrm{t}$

$p_{t} \quad$ consumer price index at time $\mathrm{t}$

$\gamma_{t} \quad$ labour productivity at time $\mathrm{t}$

$U_{t} \quad$ unemployment rate at time t

$D_{f_{i x}}$ dummy variable at time $t$ :

$$
D_{f i x_{t}}=\left\{\begin{array}{l}
1 \text { when the exchange rate is stable } \\
0 \text { otherwise }
\end{array}\right.
$$

$\Delta \quad$ first difference operator

$a_{i}, a_{i 0} \quad(\mathrm{i}=0,1,2,3,4)$ parameters to be estimated

a parameter to be estimated

$\varepsilon_{t} \quad$ error term

$w_{t}, p_{t}$ and $\gamma_{t}$ are the logarithms of the corresponding variables.

The second part of this equation, containing the level variables with one lag, estimates the long-run relationship between the variables. Such a long-run relationship, however, is susceptible to short-term deviations, which are captured in the first part of the equation, containing the first differences (Engle and Granger 1987, see 4.3 for a description of the estimation procedure).

Data from the European statistical office, Eurostat, are used covering the period between 1960 and 1996. The endogenous variable is the increase in wage from one year to the next. The first objective is to assess the degree of existing wage flexibility for all six countries. In particular, the influence of developments in productivity, prices and unemployment on wage increases will be analysed. It will be examined whether wage behaviour was steady over time, or whether the change in trend observed in the descriptive analysis can be confirmed econometrically. Last but not least, the wage equation will also aim to highlight the role of the exchange rate in wage determination. For this purpose, a dummy variable has been introduced, which takes the value ' 1 ' when the exchange rate is "stable" and the value ' 0 ' when the exchange rate is "flexible". "Stable" here means that exchange rate variability has 
remained under a certain critical value in the three years around a specific year. Exchange rate variability is defined here as

$$
\frac{\left|\Delta W k_{t-1}\right|+\left|\Delta W k_{t}\right|+\left|\Delta W k_{t+1}\right|}{3} .
$$

The critical value under which the exchange rate is found "stable" has been fixed, admittedly somewhat ad hoc, at $2.5 \%$. By fixing this value, attention was paid to obtaining a sufficient number of "stable" years, so that it makes sense to integrate this variable in the equation. The values of this dummy variable are summarised in a table in Appendix A3. By interpreting the results, one should be careful that annual data are used, which smoothes the actual fluctuations of the exchange rate. Moreover, one should keep in mind that a situation with "stable" exchange rates as defined above is not really comparable to a situation of monetary union, where exchange rate stability is far more credible and can be integrated in the expectations of economic agents. Therefore, the reactions observed - if any - could turn out to be even stronger.

Further tables in the appendix give an overview of the means and standard deviations of used data.

\subsection{Estimation}

All estimations were computed with the software package E-Views. To estimate the wage equation of the error-correction form specified above, two methods are possible. First, it is possible to estimate the equation in one step with the method of ordinary least squares, which would produce all coefficients at once. Or one can apply the two-step procedure suggested by Engle and Granger (1987). In the first step, the long-run relationship between the level variables is estimated with OLS. In the second-step, the estimated residuals, with one lag, of the static (long-run) wage equation are included as an error-correction term in the dynamic (short-run) wage equation. The advantage of using this two-step approach is that it enables one to achieve more degrees of freedom, which particularly makes sense in view of the limited number of observations. Furthermore, this approach avoids the technical problems, which tend to appear with E-Views, especially while testing, in the one-step-estimation due to the non-linearity of the parameters. Conversely, the two-step approach implies a certain efficiency loss and the long-run coefficients tend to be somewhat biased and therefore problematic to interpret. That is why both methods were applied complementarily, leading to only slightly different results in terms of coefficients.

The coefficients in the dynamic equation measure the short-run effect of the variables on wage increases. The coefficient in the static equation measures the long-run equilibrium between the variables. Finally, the coefficient ' $a$ ' for the error-correction term captures the percentage of deviation from the long-run equilibrium which is corrected in the next period, and therefore the adjustment speed towards the long-run equilibrium after a disturbance.

Prior to the estimation itself, one has to check whether the variables have the same order of integration and whether they are co-integrated. This is important since co-integration implies that the variables do not drift apart over time and that there exists a long-run equilibrium. Following usual practice, we applied for this purpose Augmented Dickey-Fuller (ADF) tests to measure co-integration.

\subsection{Results}

\subsubsection{Cointegration}

First of all, with the help of the ADF test, we examined whether the level variables in the long-run equation possess the same order of integration and whether they are cointegrated. The null hypothesis of the ADF test is that there is a unique root and that the series is not stationary. By applying this test on the residuals in the Netherlands, in Germany and in Portugal, we found that the null hypothesis was rejected to $1 \%$. For Spain, it was rejected to 5\%. It means that the residuals of the longrun estimation are stationary for those countries and consequently that the variables can be seen as being cointegrated. Only in the case of France, was the hypothesis of non-stationary not rejected. However, one should keep in mind that the null and the alternative hypotheses do not stand on the same level. The null hypothesis is only rejected if there is strong 
evidence against it. If the null hypothesis stood for 'stationary', the results could be quite different (Maddala 1992). That is why a complementary test was applied on the long-run equation for France : the CRDW (Cointegrating Regression Durbin Watson) test. This test is based on the Durbin Watson statistics of the estimated equation. The null hypothesis is now that the variables are co-integrated. When the Durbin Watson statistics is greater than 0.511 ( $1 \%$ significance level), 0.386 ( $5 \%$ significance level) or 0.322 ( $10 \%$ significance level), the variables can be considered as cointegrated (Gujarati 1995). By applying this test, we find that the level variables in France are cointegrated with a 5\% significance level.

\subsubsection{Wage equation}

Descriptive statistics of the variables included in the wage equation can be found in Appendix A4 and in Appendix A5. The following table gives an overview of the estimation results. 
Table 1: Estimated coefficients* of the wage equation

Endogenous variable : $\Delta w_{t}$

\begin{tabular}{|l|c|c|c|c|c|c|}
\cline { 2 - 7 } \multicolumn{1}{c|}{} & $\mathrm{NL}$ & $\mathrm{D}$ & $\mathrm{F}$ & $\mathrm{I}$ & $\mathrm{E}$ & $\mathrm{P}$ \\
\hline$\Delta p_{t}$ & 0.73 & 0.66 & 0.83 & 0.91 & 0.64 & 0.33 \\
& $(4.74)$ & $(3.60)$ & $(8.42)$ & $(10.89)$ & $(5.06)$ & $(2.31)$ \\
\hline$\Delta \gamma_{t}$ & 0.88 & 0.70 & 0.63 & 0.49 & 0.92 & - \\
& $(4.80)$ & $(4.67)$ & $(4.79)$ & $(2.50)$ & $(4.99)$ & \\
\hline$\Delta U_{t}$ & - & -0.64 & - & -1.81 & - & - \\
& & $(-1.78)$ & & $(-1.81)$ & & \\
\hline$\Delta w_{t-1}$ & 0.33 & 0.53 & 0.39 & 0.51 & 0.41 & 0.57 \\
& $(3.08)$ & $(5.09)$ & $(4.51)$ & $(5.59)$ & $(3.56)$ & $(3.44)$ \\
\hline$\alpha$ & -0.36 & -0.42 & -0.26 & -0.35 & -0.39 & -0.32 \\
& $(-3.88)$ & $(-4.14)$ & $(-4.16)$ & $(-2.25)$ & $(-2.20)$ & $(-2.33)$ \\
\hline$p_{t-1}$ & 1 & 1.16 & 1.12 & 1 & 1 & 0.88 \\
& & $(11.05)$ & $(15.01)$ & & & $(21.52)$ \\
\hline$\gamma_{t-1}$ & 1.36 & 1.09 & 0.95 & 1.18 & 1.19 & 1.25 \\
& $(23.97)$ & $(8.56)$ & $(9.15)$ & $(22.72)$ & $(27.63)$ & $(16.25)$ \\
\hline$U_{t-1}$ & -1.60 & -2.17 & -1.92 & -1.46 & -1.13 & - \\
& $(-4.21)$ & $(-3.80)$ & $(-1.82)$ & $(-2.54)$ & $(-10.77)$ & \\
\hline$D_{f i x}$ & -0.4 & - & - & -0.03 & -0.05 & -0.09 \\
& $(-3.00)$ & & & $(-1.84)$ & $(-5.38)$ & $(-2.05)$ \\
\hline Structural & 1984 & 1989 & 1990 & 1994 & 1988 & $1976-77$ \\
Change & -0.18 & -0.09 & -0.05 & -0.10 & -0.09 & 0.14 \\
& $(-9.58)$ & $(-4.94)$ & $(-2.36)$ & $(-3.22)$ & $(-7.73)$ & $(3.03)$ \\
\hline$R^{2}$ & 0.92 & 0.85 & 0.96 & 0.86 & 0.91 & 0.69 \\
\hline
\end{tabular}

*t-statistics in parentheses

\section{Source: own calculations}

\section{Structural change}

The stability of the estimation was systematically tested with the help of the CUSUM (Cumulated sum of residuals) and CUSUM $^{2}$ tests. Those tests showed that in all observed countries, the stability of the regression was not guaranteed over time. Therefore, we introduced dummy variables to account for the structural changes. In the Netherlands, a dummy-variable was introduced for 1984, in Germany for 1989, in France for 1990, in Italy for 1994, in Spain for 1988 and in Portugal for 1976-77. Those dummy variables take the value " 1 " for all years after the indicated years, and the value " 0 " otherwise. In the case of Portugal, the dummy variable only concerns the two years 1976 and 1977, where there were such changes in wage developments that it would have disturbed the results of the regression. In all countries, the coefficients in front of the dummy variable - with the exception of Portugal - were negative, which means that a change occurred towards a more restrictive wage policy after the indicated years. This trend change is especially pronounced in the Netherlands. As far as Portugal is concerned, the coefficient is positive, which accounts for the fact that during the two years 1976 and 1977, wage policy was significantly more expansive than in the rest of the period. To summarise, the econometric analysis confirms that wage policy has become more moderate in the six observed countries. 


\section{Flexibility of wage behaviour regarding unemployment}

The results in the table show that unemployment has a negative impact on wage increases, provided its influence is significant. In most countries (Netherlands, France, Spain), the level of unemployment has an influence on wage behaviour, but not short-term developments. In Portugal, unemployment has no influence at all on wage determination, neither through its level nor through its short-run developments. However, unemployment in Portugal has shown to have developed more favourably than in the other European countries on average in the second half of the period examined. This could explain why this variable does not play a decisive role at the end of the period. This assumption is confirmed by further partial regressions. If one carries out one additional regression for the period between 1960 and 1981, one finds that the employment level, but not employment developments, has a strong restrictive effect on wage increases (-5.35 with a significance level of 5\%). For the following period 1982-96, however, unemployment has no significant influence at all on wages in Portugal. The greatest influence on wage increases was the level of unemployment in Germany and in Italy. In both countries wage policy took the level of unemployment into account, as well as the short-term developments in unemployment. However, in Germany the level of unemployment played a decisive role, while in Italy it was the short-term developments.

\section{Flexibility of wage behaviour regarding price developments}

In the Netherlands, Italy and Spain, the long-run influence of prices on wages is not significantly different from a coefficient of 1 . That is why the coefficients were restricted to 1 . F-tests show that these restrictions are acceptable. This shows that in these countries, wages follow the price trend in the long run. However, one should take note that the inflation rate is very low in the Netherlands compared to Italy and Spain, i.e. following the price trend means that wage increases were much higher in Spain and Italy than in the Netherlands. In France and Germany, wages developed overproportionally to price developments. Portugal is the only country where the coefficient is less than 1 , but the rate of inflation was much higher there than in France or Germany. The short-term influence of inflation is quite different from one country to the other. The coefficients were distributed between 0.33 (Portugal) and 0.91 (Italy). In Italy, the adjustment speed of wages to inflation is particularly high $(91 \%$ within one year, and the coefficient turned out to be very significant). This is due to the system of indexation of wages on the rate of inflation, the so-called "scala mobile". This system was not abolished until 1993. In Spain and Portugal, the coefficient was comparatively low. This could be the result of the strong control of wage determination in those countries, particularly during the years of dictatorship. In France, the adjustment of wages to inflation was faster than in the hard currency countries. Also wage increases in the preceding years played a role in wage developments in all the countries observed. This indicates that wage negotiators tend to take the wage increase of the preceding year as a basis for negotiating wages. Portugal, Italy and Germany are particularly affected by this phenomenon, unlike the Netherlands.

\section{Flexibility of wage behaviour regarding productivity}

Portugal is the only country where increases in productivity have had no significant influence on wage developments. However, the productivity level seems to have a significant influence on wages in the long run. All other countries react in a significant way to productivity increases as well as levels. In Germany and France, the long-run productivity coefficient is not very different from 1 . This indicates that those countries focus their wage policy towards productivity in a particularly strict way. It is only in France that the long-run coefficient lies slightly below 1 . At the other extreme, the long-run productivity coefficient lies above 1 in the Netherlands, Spain and Portugal. The high value of the coefficient for the Netherlands was somewhat unexpected. 


\section{Adjustment speed}

The meaning of the coefficient $\alpha$ in front of the error-correction term has already been explained. This coefficient measures the adjustment speed. The higher this coefficient, the faster the adjustment to the long-run equilibrium.

In all countries, the coefficient in front of the error-correction term is negative and proves very significant. This is not very surprising if the variables are really cointegrated. The absolute value of the coefficient $\alpha$ is smaller than 0.45 in all countries, i.e. less than $45 \%$ of the deviation from the long-run equilibrium is corrected within one year. Germany performs best, followed by Spain, the Netherlands and Italy. The countries with the lowest wage flexibility are Portugal and, above all, France.

\section{Influence of the exchange rate regime}

The results from the table show that the stability of the exchange rate had a dampening effect on wage increases. In all countries where the influence of stable exchange rates proved significant, the coefficient in front of the dummy variable is negative. This is particularly true for the southern European countries. The southern European country where the restrictive influence of the exchange rate regime on wages was greatest is Portugal. In Italy, this effect was weaker. As far as France and Germany were concerned, a significant effect of the exchange rate stability could not be identified. Conversely, a restrictive effect was found in the Netherlands. Nevertheless, this has to be seen in relative terms particularly in view of the many years with stable exchange rates in the Netherlands (see Appendix).

The econometric analysis shows that the exchange rate regime had a significant influence on wage behaviour, especially in the southern European countries : indeed, the experience of the past shows that stable exchange rates led to a more moderate wage expansion in the southern countries. This suggests that the transition to EMU, which implies de facto stable exchange rates, should lead to a more moderate policy, especially in those countries which traditionally conducted an expansive wage policy.

\section{Conclusion}

This paper aimed at evaluating the possible consequences of the forthcoming European and Monetary Union on wage behaviour. It was shown that EMU does not influence wage policy directly, but rather indirectly, through its implications on other areas of economic policy, primarily on monetary policy. As a result, EMU implies an increasing pressure on wage policy to serve as a flexible adjustment variable, since other adjustment mechanisms shall cease to exist.

In the second part of this paper, we provided some answers to the question whether wage policy in Europe is likely to be able to take account of its redefined role under EMU by showing the required flexibility. The analysis was conducted for the specific case of six European countries which will be part of EMU in the first round. The descriptive analysis showed that in the past, European countries conducted an expansive wage policy, though much more pronounced in the southern European countries. However, this competitive disadvantage of the southern European countries turned out to be more than compensated by exchange rate developments. This is why the empirical analysis examined the question whether fewer devaluation possibilities within EMU should lead to a favourable shift in the competitive positions of the northern European countries, or whether the countries will adapt and change their wage behaviour. The descriptive analysis has shown that a trend shift has occurred in 
wage determination, which, on the eve of EMU, has become more moderate, as shown by the developments in unit labour costs. This trend could be accelerated by EMU coming into effect. The econometric analysis provides an argument for this: The stability of exchange rates has shown to have had a dampening effect on wage increases in the past, particularly in the southern European countries. EMU could bring about even stronger effects as the stability of exchange rates is far more credible in a monetary union and can be integrated in the expectations of economic agents in a more consequent way. Whether the extent of these effects will be sufficient to prevent a shift in relative competitive positions, however, remains to be seen. 


\section{References}

Boockmann, Bernhardt (1999): Trade Union Strategies and Labour Market Outcomes under $E M U$, ZEW Mannheim, mimeo.

Herbert S. Buscher (1999): Business Cycles in EU Member States, ZEW Mannheim, mimeo.

Büttner, Thiess (1999): Regional Fiscal Stabilization by Fiscal Flows and the Need for Fiscal Equalization in EMU, ZEW Mannheim, mimeo.

Busch, Klaus (1993): Gewerkschaftliche Tarifpolitik in Europa: Handlungsbedingungen und möglichkeiten bei unterschiedlichen europäischen Einigungsstrategien, Düsseldorf (HansBöckler-Stiftung, HBS-Manuskripte Nr. 124)

De Grauwe, Paul (1994): The Economics of Monetary Union, Oxford (Oxford University Press)

Dohse, Dirk, Krieger-Boden, Christiane (1998): Währungsunion und Arbeitsmarkt: Auftakt zu unabdingbaren Reformen, Kieler Studie Nr. 290, Hrsg. Horst Siebert, Institut für Weltwirtschaft an der Universität Kiel, Tübingen (Verlag Mohr Siebeck)

EC-Commission (1991): Ein Markt, eine Währung: Potentielle Nutzen und Kosten der Errichtung einer Wirtschafts- und Währungsunion, Studie der EG-Kommission, GD II (Wirtschaft und Finanzen), Michael Emerson, Bruxelles

Eichengreen, Barry (1990): Is Europe an Optimum Currency Area?, London (CEPR Discussion Paper No. 478)

Engle, R.F., Granger, C.W.J. (1987): Co-integration and Error Correction: Representation, Estimation and Testing, Econometrica 55, No. 2

Fröhlich, Hans-Peter; Klös, Hans-Peter und Kroker, Rolf (1997): Lohnpolitik in der Europäischen Währungsunion, Köln (Institut der Deutschen Wirtschaft, Deutscher InstitutsVerlag, Beiträge zur Wirtschafts- und Sozialpolitik Nr. 234)

Gujarati, Damodar N. (1995): Basic Econometrics, $3^{\text {rd }}$ ed., New York

Hardes (1994): Die Entwicklung der Lohnstückkosten im internationalen Vergleich

Horn, Gustav-Adolf, Scheremet, Wolfgang und Zwiener, Rudolf (1997): Rahmenbedingungen für den Arbeitsmarkt in einer erfolgreichen Wirtschafts- und Währungsunion der EUMitgliedstaaten, Berlin (Deutsches Institut für Wirtschaftsforschung)

Hübner, Kurt und Bley, Andreas (1996): Lohnstückkosten und internationale Wettbewerbsfähigkeit, Marburg (Schüren, Hans Böckler Stiftung)

Layard, Richard, Nickell, Stephen, and Jackman, Richard (1991): Unemployment, Macroeconomic Performance and the Labour Market, New York (Oxford University Press) 
Lesch, Hagen (1995): Strategische Lohnpolitik in einer Europäischen Währungsunion, Bonn (Institut "Finanzen und Steuern", IFSt-Schrift Nr. 342)

Maddala (1992): Introduction to Econometrics

Matthes, Heinrich (1992): Währungsunion mit Peripherie?, in: Wirtschaftsdienst Nr. 12, Hamburg

Müller, Claudia and Buscher, Herbert S. (1999a): Exchange Rate Volatility Effects on the German Labour Market: A Survey of Recent Results and Extensions, ZEW Mannheim, mimeo.

Müller, Claudia and Buscher, Herbert S. (1999b): The Impact of Monetary Instruments on Shock Absorption in EU-Countries, ZEW Mannheim, mimeo.

Müller, Claudia and Heinemann, Friedrich (1999c): Capital Mobility within EMU, ZEW Mannheim, mimeo.

Mundell, Robert (1961): A Theory of Optimum Currency Areas, in: The American Economic Review No. 51, 657-665

Puhani, Patrick A. (1999): Labour Mobility - An adjustment Mechanism in Euroland? Empirical Evidence for Western Germany, France and Italy, ZEW Mannheim, mimeo.

Siebert, Horst (1997): Zu den Voraussetzungen der Europäischen Währungsunion, Kiel (Institut für Weltwirtschaft, Kieler Diskussionsbeiträge Nr 289)

Sievert, Olaf (1993): "Geld, das man nicht selbst herstellen kann: Ein ordnungspolitisches Plädoyer für die Europäische Währungsunion”, in: Bofinger, Peter: Währungsunion oder Währungschaos? Was kommt nach der D-Mark, Wiesbaden, S. 13-24

Tyrväinen, Timo (1995): Wage Determination in the Long Run, Real Wage Resistance and Unemployment: Multivariate Analysis of Cointegrating Relations in 10 OECD Economies, Helsinki (Bank of Finland Discussion Papers) 


\section{APPENDIX}


Appendix A1:

Nominal labour income and productivity levels in selected European countries 1996 $(\mathrm{EU} 15=100)$

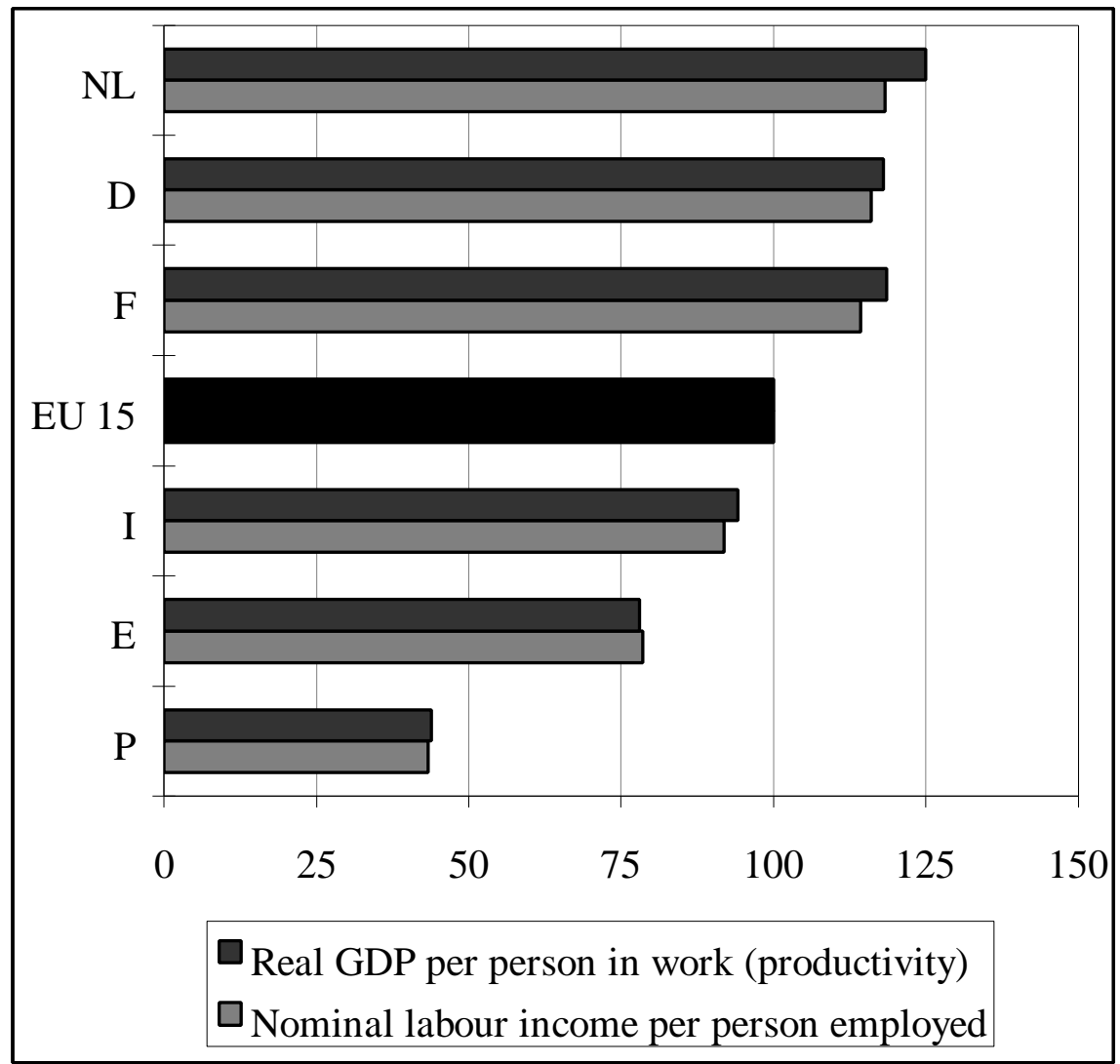

Source: Eurostat 
Appendix A2:

Consumer Price Index 1960-1996

Consumer Price Index 1960-1996

Germany, France, Netherlands

Percentage change

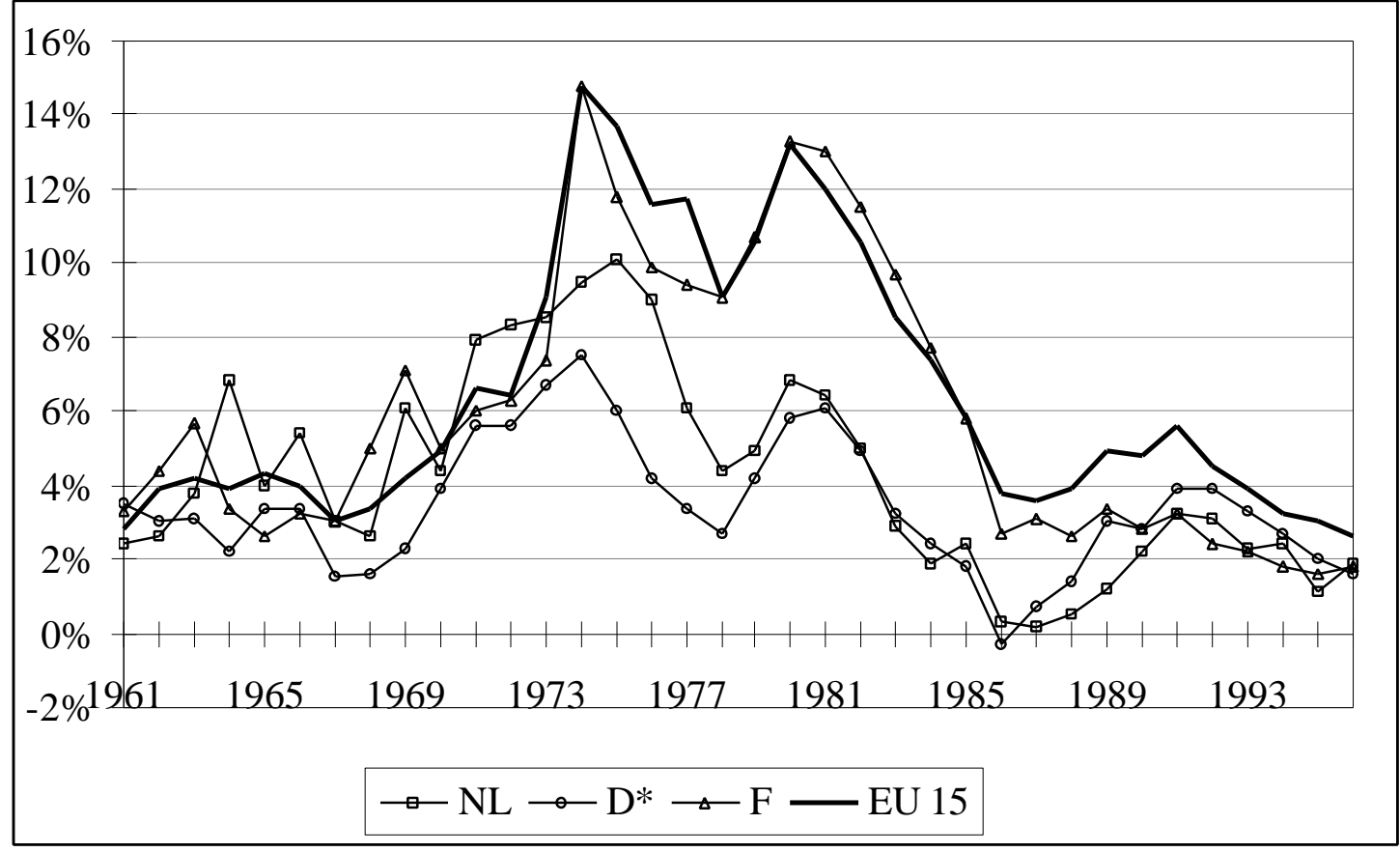

* Until 1994: former West-Germany

Source: Eurostat

Consumer Price Index 1960-1996

Germany, France, Netherlands

Percentage change

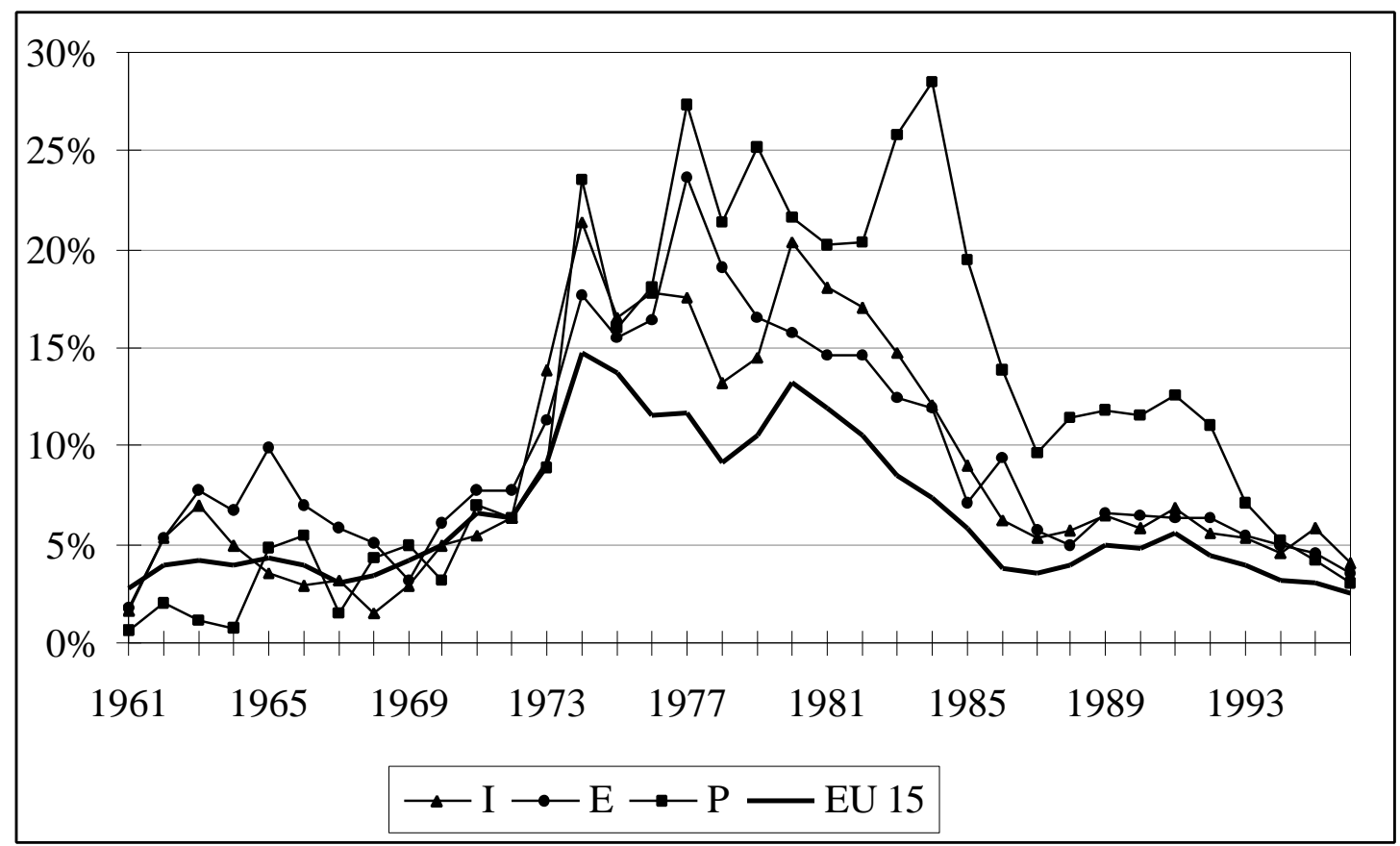

* Until 1994: former West-Germany

Source: Eurostat 
Appendix A3:

Value of the dummy variable - Stability of the nominal effective exchange rate

\begin{tabular}{|c|c|c|c|c|c|c|}
\hline & $\mathrm{NL}$ & D & $\mathrm{F}$ & I & $\mathrm{E}$ & $\mathrm{P}$ \\
\hline 1960 & - & - & - & - & - & - \\
\hline 1961 & - & - & - & - & - & - \\
\hline 1962 & 1 & 1 & 1 & 1 & 1 & 1 \\
\hline 1963 & 1 & 1 & 1 & 1 & 1 & 1 \\
\hline 1964 & 1 & 1 & 1 & 1 & 1 & 1 \\
\hline 1965 & 1 & 1 & 1 & 1 & 1 & 1 \\
\hline 1966 & 1 & 1 & 1 & 1 & 1 & 1 \\
\hline 1967 & 1 & 1 & 1 & 1 & 0 & 1 \\
\hline 1968 & 1 & 1 & 1 & 1 & 0 & 1 \\
\hline 1969 & 1 & 0 & 0 & 1 & 0 & 1 \\
\hline 1970 & 1 & 0 & 0 & 1 & 1 & 1 \\
\hline 1971 & 1 & 0 & 0 & 1 & 1 & 1 \\
\hline 1972 & 1 & 0 & 0 & 0 & 1 & 1 \\
\hline 1973 & 0 & 0 & 0 & 0 & 1 & 1 \\
\hline 1974 & 0 & 0 & 0 & 0 & 1 & 1 \\
\hline 1975 & 0 & 0 & 0 & 0 & 0 & 0 \\
\hline 1976 & 0 & 0 & 0 & 0 & 0 & 0 \\
\hline 1977 & 0 & 0 & 0 & 0 & 0 & 0 \\
\hline 1978 & 0 & 0 & 1 & 0 & 0 & 0 \\
\hline 1979 & 1 & 0 & 1 & 0 & 0 & 0 \\
\hline 1980 & 1 & 0 & 0 & 0 & 0 & 0 \\
\hline 1981 & 0 & 0 & 0 & 0 & 0 & 0 \\
\hline 1982 & 0 & 0 & 0 & 0 & 0 & 0 \\
\hline 1983 & 0 & 0 & 0 & 0 & 0 & 0 \\
\hline 1984 & 1 & 1 & 0 & 0 & 0 & 0 \\
\hline 1985 & 0 & 0 & 0 & 0 & 1 & 0 \\
\hline 1986 & 0 & 0 & 1 & 0 & 1 & 0 \\
\hline 1987 & 0 & 0 & 0 & 0 & 1 & 0 \\
\hline 1988 & 1 & 0 & 1 & 1 & 1 & 0 \\
\hline 1989 & 1 & 0 & 0 & 0 & 0 & 0 \\
\hline 1990 & 1 & 0 & 0 & 1 & 0 & 1 \\
\hline 1991 & 1 & 0 & 0 & 0 & 1 & 1 \\
\hline 1992 & 1 & 1 & 0 & 0 & 0 & 0 \\
\hline 1993 & 1 & 1 & 1 & 0 & 0 & 0 \\
\hline 1994 & 0 & 0 & 1 & 0 & 0 & 0 \\
\hline 1995 & 1 & 0 & 1 & 0 & 0 & 0 \\
\hline 1996 & - & - & - & - & - & - \\
\hline
\end{tabular}




\section{Appendix A4: \\ Definition of the variables}

The names of the variables reported in the following tables are defined as follows:

Firstly, the name of the country is indicated :

$\begin{array}{ll}\text { NL } & \text { Netherlands } \\ \text { D } & \text { Germany } \\ \text { F } & \text { France } \\ \text { I } & \text { Italy } \\ \text { E } & \text { Spain } \\ \text { P } & \text { Portugal }\end{array}$

Then, the mark of the variable :

$\begin{array}{ll}\text { ALK } & \text { unemployment } \\ \text { ALKp } & \text { increase in unemployment (in \%) } \\ \text { Wnom } & \text { nominal wage } \\ \text { Wnomp } & \text { increase in nominal wage } \\ \text { Wreal } & \text { real wage } \\ \text { Wrealp } & \text { increase in real wage } \\ \text { Prod } & \text { productivity } \\ \text { Prodp } & \text { increase in productivity } \\ \text { CPI } & \text { consumer price index } \\ \text { CPIp } & \text { increase in consumer price index } \\ \text { LSKnom } & \text { nominal unit labour costs } \\ \text { LSKnomp } & \text { increase in nominal unit labour costs } \\ \text { LSKreal } & \text { real unit labour costs } \\ \text { LSKrealp } & \text { increase in real unit labour costs } \\ \text { Wk } & \text { nominal effective exchange rate } \\ \text { Wkp } & \text { increase in nominal effective exchange rate }\end{array}$




\section{Appendix A5:}

\section{Descriptive statistics of the variables included in the wage equation}

\begin{tabular}{|c|c|c|c|c|c|c|c|c|c|}
\hline & & \multicolumn{2}{|c|}{ WNOMp } & \multicolumn{2}{|c|}{ CPIp } & \multicolumn{2}{|c|}{ PRODp } & \multicolumn{2}{|c|}{ ALKp } \\
\hline & & Mean & Stand. Dev. & Mean & Stand. Dev. & Mean & Stand. Dev. & Mean & Stand. Dev. \\
\hline \multirow{3}{*}{ NL } & Total & 7.12 & 4.83 & 0.04 & 0.03 & 2.45 & 1.77 & 0.10 & 0.30 \\
\hline & Fix & 7.47 & 4.72 & 0.04 & 0.02 & 2.76 & 1.85 & 0.11 & 0.32 \\
\hline & Flex & 6.94 & 5.13 & 0.05 & 0.03 & 2.15 & 1.67 & 0.14 & 0.28 \\
\hline \multirow{3}{*}{ D } & Total & 6.39 & 3.21 & 0.03 & 0.02 & 2.64 & 1.70 & 0.12 & 0.42 \\
\hline & Fix & 6.25 & 2.3 .3 & 0.03 & 0.01 & 3.29 & 1.97 & 0.17 & 0.57 \\
\hline & Flex & 6.44 & 3.46 & 0.04 & 0.02 & 2.40 & 1.56 & 0.12 & 0.34 \\
\hline \multirow{3}{*}{$\mathrm{F}$} & Total & 8.99 & 4.53 & 0.06 & 0.04 & 2.92 & 1.60 & 0.07 & 0.12 \\
\hline & Fix & 7.36 & 3.88 & 0.04 & 0.0 .3 & 3.48 & 1.73 & 0.08 & 0.14 \\
\hline & Flex & 10.38 & 4.51 & 0.08 & 0.04 & 2.51 & 1.28 & 0.07 & 0.11 \\
\hline \multirow{3}{*}{ I } & Total & 12.37 & 5.83 & 0.09 & 0.06 & 3.29 & 2.40 & 0.02 & 0.09 \\
\hline & Fix & 11.08 & 3.75 & 0.04 & 0.02 & 5.02 & 2.10 & 0.00 & 0.12 \\
\hline & Flex & 13.58 & 6.53 & 0.12 & 0.06 & 2.22 & 1.78 & 0.04 & 0.07 \\
\hline \multirow{3}{*}{ E } & Total & 13.36 & 6.19 & 0.09 & 0.05 & 3.91 & 2.59 & 0.08 & 0.18 \\
\hline & Fix & 13.70 & 4.81 & 0.08 & 0.03 & 4.71 & 2.40 & 0.02 & 0.19 \\
\hline & Flex & 13.62 & 7.03 & 0.11 & 0.06 & 3.05 & 1.78 & 0.13 & 0.17 \\
\hline \multirow{3}{*}{$P$} & Total & 15.65 & 8.01 & 0.12 & 0.08 & 4.10 & 3.03 & 0.07 & 0.29 \\
\hline & Fix & 1.3.6.5 & 7.56 & 0.07 & 0.06 & 5.67 & 3.16 & -0.02 & 0.10 \\
\hline & Flex & 18.33 & 7.38 & 0.17 & 0.07 & 2.93 & 2.47 & 0.13 & 0.38 \\
\hline
\end{tabular}

\begin{tabular}{|c|c|c|c|c|c|c|c|c|c|}
\hline & & \multicolumn{2}{|c|}{ WNOM } & \multicolumn{2}{|c|}{ CPI } & \multicolumn{2}{|c|}{ PROD } & \multicolumn{2}{|c|}{ ALK } \\
\hline & & Mean & Stand. Dev. & Mean & Stand. Dev. & Mean. & Stand. Dev. & Mean & Stand. Dev. \\
\hline \multirow{3}{*}{ NL } & Total & 610.39 & 348.73 & 267.07 & 118.06 & 176.35 & 43.51 & 0.05 & 0.03 \\
\hline & Fix & 555.70 & 374.76 & 249.74 & 126.09 & 170.01 & 46.57 & 0.04 & 0.03 \\
\hline & Flex & 735.35 & 192.59 & 306.94 & 72.52 & 193.49 & 18.93 & 0.07 & 0.03 \\
\hline \multirow{3}{*}{ D } & Total & 454.45 & 254.22 & 203.65 & 74.62 & 181.23 & 45.24 & 0.03 & 0.03 \\
\hline & Fix & 328.78 & 280.72 & 168.36 & 81.55 & 1.53 .79 & 49.60 & 0.02 & 0.02 \\
\hline & Flex & 516.79 & 193.31 & 221.43 & 58.39 & 196.24 & 28.97 & 0.04 & 0.02 \\
\hline \multirow{3}{*}{ F } & Total & 915.07 & 717.61 & 391.19 & 253.76 & 198.51 & 54.32 & 0.06 & 0.04 \\
\hline & Fix & 851.58 & 792.79 & 365.48 & 278.11 & 187.58 & 62.42 & 0.06 & 0.04 \\
\hline & Flex & 978.89 & 603.62 & 417.60 & 216.81 & 211.62 & 34.92 & 0.06 & 0.03 \\
\hline \multirow{3}{*}{ I } & Total & 2041.48 & 2060.86 & 706.45 & 631.23 & 216.25 & 60.62 & 0.07 & 0.02 \\
\hline & Fix & 883.37 & 1521.90 & 338.00 & 467.12 & 171.65 & 51.39 & 0.06 & 0.02 \\
\hline & Flex & 2653.65 & 1894.69 & 903.49 & 572.98 & 246.17 & 33.81 & 0.08 & 0.02 \\
\hline \multirow{3}{*}{ E } & Total & 2866.87 & 2847.29 & 843.09 & 753.46 & 262.04 & 90.93 & 0.11 & 0.08 \\
\hline & $F i x$ & 1979.49 & 2357.41 & 614.35 & 641.01 & 233.40 & 87.82 & 0.08 & 0.08 \\
\hline & Flex & 3553.48 & 2782.59 & 1021.26 & 725.87 & 294.20 & 69.67 & 0.13 & 0.07 \\
\hline \multirow{3}{*}{$P$} & Total & 4341.66 & 5515.33 & 1327.67 & 1550.82 & 259.81 & 98.53 & 0.05 & 0.02 \\
\hline & Fix & 1761.67 & 3917.38 & 560.73 & 1099.67 & 194.75 & 80.96 & 0.03 & 0.01 \\
\hline & Flex & 6146.23 & 5288.98 & 1880.51 & 1473.77 & 319.41 & 53.84 & 0.07 & 0.01 \\
\hline
\end{tabular}

"Fix" stands for fixed (stable) exchange rates.

"Flex" stands for flexible (unstable) exchange rates. 